\title{
A Rapid Review on Domestic Violence as a Silent Consequence in Corona Time: A Double Pandemic
}

\author{
Seyedeh Zeynab Hoseinnezhad ${ }^{1}$, Forouzan Elyasi ${ }^{2}$, Zohreh Shahhosseini ${ }^{3 *}$
}

\author{
${ }^{1}$ Student Research Committee, Mazandaran University of Medical Sciences, Sari, IRAN \\ ${ }^{2}$ Sexual and Reproductive Health Research Center, Psychiatry and Behavioral Sciences Research Center, Addiction Research Institute, Mazandaran University of \\ Medical Sciences, Sari, IRAN \\ ${ }^{3}$ Sexual and Reproductive Health Research Center, Mazandaran University of Medical Sciences, Sari, IRAN \\ *Corresponding Author: zshahhosseini@yahoo.com
}

Citation: Hoseinnezhad, S. Z., Elyasi, F. and Shahhosseini, Z. (2021). A Rapid Review on Domestic Violence as a Silent Consequence in Corona Time: A Double Pandemic. European Journal of Environment and Public Health, 5(1), em0062. https://doi.org/10.29333/ejeph/8577

\begin{tabular}{|c|c|}
\hline ARTICLE INFO & ABSTRACT \\
\hline Received: 21 Jun. 2020 & Objectives: Domestic violence refers to the violent and domineering behavior of a family member against a \\
\hline Accepted: 14 Aug. 2020 & $\begin{array}{l}\text { member or other members of the same family, which some environmental factors play a role in creating and } \\
\text { exacerbating. According to the current situation, domestic violence is likely to create or exacerbate. The aim of } \\
\text { the present study is to determine domestic violence and the factors influencing its occurrence in the COVID-19 }\end{array}$ \\
\hline
\end{tabular}
era.

Methods: This study was conducted in 1399 with designing of the steps: study question, search, which in databases such as PubMed, Scopus, Springer, Elsevier, Cochrane Library, Science Direct, Web of Science, Magiran with keywords like "Domestic Violence”, "Quaid 19", "Consequences”, “Crisis”, "Related Factors" and their English equivalents. After identifying the relevant studies from 2002 to 2020, and after screening the title, the selection of studies was performed. From the 72 abstract and full texts, 8 studies were utilized in the findings and discussion section.

Results: Consequences of the COVID-19 virus can be a risk factor for the creation or exacerbation of domestic violence. Social distancing, unemployment, and job loss, and fear of infection by the virus are all important factors that can be sources for increasing anxiety and stress in people, which can eventually lead to domestic violence during this time.

Conclusion: Considering different articles about the factors affecting the creation or exacerbation of domestic violence and COVID-19, it is inferred that COVID-19 can be a risk factor for domestic violence.

Keywords: corona, domestic violence, double pandemic

\section{INTRODUCTION}

Domestic Violence (DV) refers to the threatening, aggressive behavior of other family members, which can be physical, sexual, psychological, or economic. It can be categorized as child abuse, partner abuse, and elderly abuse (Peterman et al., 2020). According to the CDC, every year, in non-critical condition, about 1 out of every 4 women and 1 in 10 men experience a form of violence (Peterman et al., 2020). The COVID-19 pandemic began in China in late December 2019. The prevalence of this virus varies according to the conditions of the region, including the level of health, the existence of vulnerable populations, including the elderly (Cohen, 2020; Radwan et al., 2021). As a result, people were encouraged to keep their social distance, stay at home, and keep healthy. Some countries banned participation in the community. This has had a negative impact on the social and economic stability of the countries involved. Social distancing, a decline in income, unemployment and quitting jobs, fear of contracting the virus, and school closures are among the causes of stress and severe anxiety in people (Cahapay, 2020; van Gelder et al., 2020). In these circumstances, the WHO acknowledged that while these measures could be effective in controlling the spread of the disease, the depth of its impact on society will have social, economic, and psychological consequences, which will ultimately increase the likelihood of DV (World Health Organization, 2020). The purpose of the present article is to determine DV and the factors contributing to its occurrence in the COVID-19 era. It is hoped that the results of this study will be effective in designing programs in order to manage DV. 


\section{METHODS}

The present study is a short report study in which a research question (which factors affecting DV during the COVID-19 crisis?) was first raised. Then a search was carried out in Google Scholar search engine and in databases such as PubMed, Scopus, Springer, Elsevier, Cochrane Library, Science Direct, Web of Science, Magiran, and Scientific Information Database with keywords such as consequences, effective factors, Domestic Violence, coronavirus, and crisis. The number of articles found was initially 83. After removing duplicate articles using EndNote software, 72 articles remained. Then, unrelated articles that did not meet the inclusion criteria, i.e. languages other than English and Persian and the summary of the articles presented in the congresses that did not have full texts were removed and finally, the eight remaining articles in the period from 2002 to 2020, were recruited.

\section{FINDINGS AND DISCUSSION}

According to the existing literature, COVID-19 pandemic is one of the factors that can cause or exacerbate DV (NSPCC, 2020). Spending more time at home, not being able to ask for help during the violence, failure to go to judicial offices and hospitals for judicial follow-up due to fear of the illness, increasing the likelihood of drug and alcohol use at home, cultural taboos, living area and unavailability of welfare facilities, lack of awareness of how to get rid of violence, and difficulty in providing legal proof of violence have increased violence (Campbell, 2020). Reports from local police near the areas affected by COVID-19 in Hubei Province, China, indicate that partner violence in February 2020 has tripled since February 2019 (UN Women Headquarters, 2020). Also, according to the UN Women, DV reports in France have increased by $30 \%$ (UN Women Headquarters, 2020). DV calls in Argentina have increased by 25 percent since the announcement of social distancing in March 2020 (UN Women Headquarters, 2020). Also, a 30 percent increase in telephone calls in Cyprus and a 33 percent increase in calls in Singapore also indicate a rise in DV in those areas (Boserup et al., 2020). Following these events, the Portland Police Department recorded a $22 \%$ increase in DV arrests compared to the previous week. In San Antonio, Texas schools closed on March 20, 2020. Afterward, San Antonio's deputy police chief noted that calls for DV increased by $18 \%$ in March 2020 compared to March 2019. In the city of Jefferson, Alabama, calls for DV increased by 27 percent, and in New York, by 10 percent in March 2020 compared to March 2019 (Rafiei, 2020). Iran was no exception as well. By creating social distancing and announcing official holidays throughout the country, as well as promoting staying at home, the number of calls to social emergency landlines, and the voice of counselors (telephone counseling developed by the Welfare Organization) in order to get rid of DV increased. Following this condition, various countries took steps in order to reduce DV. To help the victims of DV, France has stepped up its support for emergency shelters for victims of DV and has since put up emergency warning systems in public places. Increasing public awareness of DV was one of their measures (Guenfound, 2020). Following an increase in calls to social emergencies, Iran also sent a text message to the public in order to raise their awareness of how to use support systems for the victims of DV. This was followed by an increase in funding for systems that support the victims of DV (Guenfound, 2020).

Finally, it should be noted that despite the fact that the governments promote staying at home, it will not always be a safe place for everyone after all. Some people protect themselves from DV by going to shopping malls and spending time at other family members' homes. Culture areas (rural and marginalized areas), low education, previous history of DV, severe decline in economic income adequacy, history of alcohol and drug use, history of mental disorders related to DV such as borderline and antisocial personality disorders, a history of marital disputes, and young age are among the risk factors for DV, which require more attention during COVID-19 crisis (Postmus et al., 2020). Broadcasting TV programs that teach anger management skills, assertiveness, stress, and anxiety management can be helpful. Public awareness of support systems through national media and the screening of the people at risk of DV are other recommendations which could alleviate the situation.

\section{REFERENCES}

Boserup, B., McKenney, M. and Elkbuli, A. (2020). Alarming trends in US domestic violence during the COVID-19 pandemic. American Journal of Emergency Medicine. https://doi.org/10.1016/j.ajem.2020.04.077

Cahapay, M. B. (2020). Social Distancing Practices of Residents in a Philippine Region with Low Risk of COVID-19 Infection. European Journal of Environment and Public Health, 4(2), em0057. https://doi.org/10.29333/ejeph/8455

Campbell, A. M. (2020). An increasing risk of family violence during the Covid-19 pandemic: strengthening community collaborations to save lives. Forensic Science International: Reports, 100089. https://doi.org/10.1016/j.fsir.2020.100089

Cohen, P. N. (2020). The COVID-19 Epidemic in Rural U.S. Counties. European Journal of Environment and Public Health, 4(2), em0050. https://doi.org/10.29333/ejeph/8331

Guenfound, I. (2020). French women use code words at pharmacies to escape domestic violence during coronavirus lockdown. $A B C$ News. Available at: https://abcnewsgocom/International/french-womencode-words-pharmacies-escape

NSPCC. NSftPoCtC. (2020). Coronavirus (COVID-19) and keeping children safe from abuse. National Society for the Prevention of Cruelty to Children (NSPCC). Available at: https://www.nspcc.org.uk/keeping-childrensafe/reporting-abuse/coronavirus-abuse-neglectvulnerable-children/ 
Peterman, A., Potts, A., O’Donnell, M., Thompson, K., Shah, N., Oertelt-Prigione, S. and van Gelder, N. (2020). Pandemics and Violence Against Women and Children. CGD Working Paper 528. Washington, DC: Center for Global Development. Available at: https://www.cgdev.org/publication/pandemics-andviolence-against-women-and-children (Accessed: 1 April 2020).

Postmus, J. L., Hoge, G. L., Breckenridge, J., Sharp-Jeffs, N. and Chung, D. (2020). Economic abuse as an invisible form of domestic violence: A multicountry review. Trauma, Violence, \& Abuse, 21(2), 261-83. https://doi.org/ $10.1177 / 1524838018764160$

Radwan, E., Radwan, A. and Radwan, W. (2021). Challenges Facing Older Adults during the COVID-19 Outbreak. European Journal of Environment and Public Health, 5(1), em0059. https://doi.org/10.29333/ejeph/8457
Rafiei, P. (2020). Coronavirus increased domestic violence. Magiran. https://www.magiran.com/article/4028868

UN Women Headquarters. (2020). COVID-19 and ending violence against women and girls. UN. Available at: https://www.unwomen.org/en/digitallibrary/publications/2020/04/issue-brief-covid-19-andending-violence-against-women-and-girls

van Gelder, N., Peterman, A., Potts, A., O’Donnell, M., Thompson, K., Shah, N., et al. (2020). COVID-19: Reducing the risk of infection might increase the risk of intimate partner violence. EClinicalMedicine, 21, 100348. https://doi.org/10.1016/j.eclinm.2020.100348

World Health Organization. (2020). COVID-19 and violence against women: what the health sector/system can do. Available at: https://www.who.int/reproductivehealth/ publications/vaw-covid-19/en/ (Accessed: 7 April 2020). 